
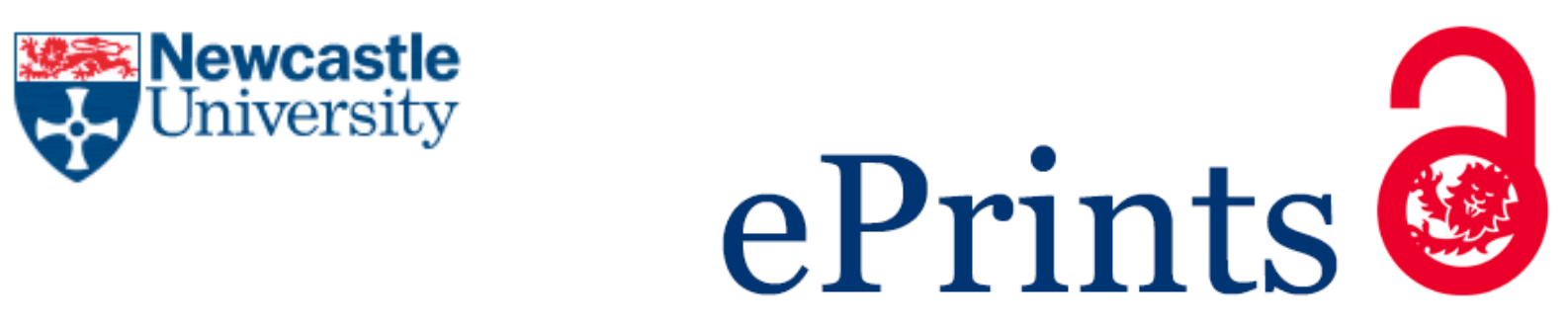

Pinkerton A, Benwell MC. Rethinking popular geopolitics in the Falklands/Malvinas sovereignty dispute: Creative diplomacy and citizen statecraft. Political Geography 2014, 38, 12-22.

\title{
Copyright:
}

(C) 2013. This manuscript version is made available under the CC-BY-NC-ND 4.0 license

DOI link to article:

http://dx.doi.org/10.1016/i.polgeo.2013.10.003

Date deposited:

$07 / 08 / 2015$

Embargo release date:

19 November 2015

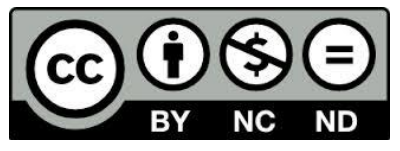

This work is licensed under a

Creative Commons Attribution-NonCommercial-NoDerivatives 4.0 International licence 


\section{Rethinking popular geopolitics in the Falklands/Malvinas sovereignty dispute: creative diplomacy and citizen statecraft.}

\section{$\underline{\text { ABSTRACT }}$}

For more than twenty years 'popular geopolitics' has proven an intriguing and fruitful field of research for political geographers. It has spurred a lasting interest in everything from movies to stamps as important cultural artefacts that reveal to their audiences the geopolitical visions of their producers. This paper, however, brings into question the 'popularity' of popular geopolitics. Using recent examples from the ongoing dispute over the Falkland Islands, we examine the influence of social media and the associated flourishing of 'citizen statecraft' which, through its production of geopolitical knowledges, hints at the possibilities of a genuinely popular geopolitics 2.o. We also examine how creative practices, understood in myriad ways in relation to 'statecraft', work to unsettle and complicate previously tidy geopolitical categories of 'the popular', the 'formal', and the 'practical'.

\section{INTRODUCTION}

The thirtieth anniversary of the 1982 Falklands/Malvinas War (the authors acknowledge the geopolitical sensitivities of naming the islands the Falklands or Malvinas given their disputed status but use the definition considered most contextually appropriate throughout the paper) was marked in 2012, as during previous anniversaries of the conflict, with moments of dignified solemnity, of sombre reflection and remembrance of the 649 Argentines, 255 British soldiers and three Falkland Islanders who died during the 74-day conflict. In the United Kingdom, Argentina and the Falkland Islands, men and women-friends, colleagues and families of the fallen, and those who just wished to pay their respects-looked upon names carved into the similarly elliptical walls of the Monumento a los caidos en Malvinas (Buenos Aires), the Blue Beach Military Cemetery (San Carlos, East Falkland) and the newly-inaugurated Falklands Memorial at the National Memorial Arboretum in Staffordshire (UK) in parallel acts of remembrance.

Unlike during previous anniversaries, however, these moments of solemnity failed to either set or reflect a mood of reconciliation and peaceful progress between 
the protagonist states. In striking contrast to the "reflective and conciliatory" tone struck in 2002 (during the 2oth anniversary) the 30th anniversary of the conflict became, instead, a lightning rod for renewed tensions in the South Atlantic. As Mark Lyall-Grant, the UK's Ambassador to the United Nations, noted, the "statesman-like" approach adopted by the UK and Argentina in 2002-which included joint commemorations for UK and Argentine casualties-gave way in 2012 to more highly politicised rhetoric. As one might anticipate, Lyall-Grant reserved his condemnation for Argentina, which he accused of "hyping up the rhetoric" for "purely domestic political reasons" (Davies 2012). Argentina's Vice President, Amado Boudou, criticized Britain's "bullying" tactics in the South Atlantic, which, he claimed, were geared, "to distract UK public opinion...from domestic questions that must be solved such as unemployment and Scotland's independence referendum and the oil in the North Sea" (Mercopress 2012a). While this kind of diplomatic sparring is neither unusual nor entirely unexpected (UK-Argentine relations have deteriorated since 2003), the suggestion that Argentina's recent behaviour on the international stage has been less than "statesman-like" is intriguing and rests, in part, on the perception that Argentina has (i) 'hyped up the rhetoric in a massive way', for (ii) 'purely political reasons'; that they are (iii) 'using every opportunity to try to internationalise the issue', and (iv) generating 'support from regional organisations', while (v) making 'a song and dance at the UN' (Davies 2012). Among Argentina's most high profile attempts to internationalise the issue of sovereignty over the Malvinas has included the careful management of 'celebrity' supporters, including the likes of Morrissey, Roger Waters and Sean Penn (see Benwell et al. 2012), and the production of filmsinspired by the tropes of commercial advertising-that visually assert Argentina's claims to the disputed islands. In internationalising sovereignty claims, the Argentine state has been assisted by sections of the Argentine public who have used social media to passionately reassert Argentina's foreign policy priorities.

Using the context of the ongoing and recently intensified debate about sovereignty over the Falkland/Malvinas Islands (Dodds 2012), this paper will draw upon an outpouring of social media content that has seen both Falkland Islanders and Argentines actively engaged in 'citizen statecraft' through the production and reproduction of 'popular' and official geopolitical discourses. In the South Atlantic context, there is, we would argue, an increasing interweaving of diplomatic and 
civilian life, and a corresponding blurring of traditional distinctions between 'intellectuals of statecraft' and 'everyday citizenry'. Twitter, Facebook, YouTube and other online forums/blogs have become the places where the sovereignty dispute is being thrashed out and governments, politicians, marketing agencies, veterans and your average Falkland Islanders, Argentines and British people are calling the shots in different ways. This is not to the exclusion of traditional media, and this paper will explore some of the new complexities in tracing the connections between 'new' and traditional media in terms of their circulation and production (Woon 2011) and, in so doing, will consider the connections between virtual/non-virtual spaces (Dittmer 2010a).

This paper explores the transformed communicational environment for public diplomacy and the ways this creates new opportunities/challenges for governments and citizens to perform statecraft. In examining escalating tensions in the South Atlantic during 2012, elite practices of diplomacy, performances of statecraft and 'scriptings' of geopolitical discourse are seen to be increasingly intertwined with (and unsettled by) notions of celebrity, instruments such as social media, and citizenries who are able to represent themselves and their own geopolitical articulations to international audiences. These relationships complicate and challenge conventional wisdoms about statecraft and diplomacy and challenge us to think more critically about issues of geopolitical agency, authority and 'power' as well as the interaction of popular, formal and practical geopolitical discourses and their sites of production, distribution and consumption. In addressing these issues, this paper sits at a confluence of several areas of growing importance within political geography, including the growing appreciation of 'the everyday' and the development of 'alternative' geopolitical frameworks and visions. This research also navigates within and between the growing literature about the potential of 'new' media to challenge/contest dominant representations of the prevailing political-economic order and, counter to that, other scholarship that suggests traditional media reinforces rather than challenges the status quo (especially geopolitics of neoliberalism; see Dittmer 2010b; Dodds 2007). This paper will show that this binary is, in reality, much more complex and contingent; media can challenge, disrupt and parody in interesting ways. While we might have become accustomed to reading about "Twitter revolutions" and the power of Facebook and YouTube in 
mobilising and co-ordinating anti-government and anti-establishment sentiment in broadsheet editorials and commentaries (e.g. Beaumont 2011), new social media is not slavishly "anti-geopolitical”. It is as diverse as the spectrum of (geo)political opinion and has, as this paper demonstrates in the context of the South Atlantic, the potential both to reinforce and reconfigure dominant state policies/geopolitical messages. Initially, however, we wish to sketch out the theoretical and conceptual landscape within which this paper has both drawn inspiration and seeks to advance.

\section{$\underline{\text { RE-CASTING GEOPOLITICS }}$}

This research is rooted in the near quarter-century of intellectual work undertaken under the banner of 'critical geopolitics' and is positioned at the productive margins between the three main discursive pillars that have supported the critical geopolitics movement: formal geopolitics, practical geopolitics and popular geopolitics. These categories-which seek to frame geopolitical discourse related to academics, policymakers and 'the public' respectively-have long been noted for their porosity and the relatively 'loose' nature of their categorisation. Nonetheless, they have proven to be remarkably robust and much of the critical geopolitics work that followed has been ready and willing to elevate these loose categorisations into 'containers' for academic reflections and analysis. This has, perhaps, been prompted by the agency-centric nature of this framework, which has focussed attention onto elite and powerful actors-both individual and institutional-and the ways in which they shape (or 'script') geopolitical discourses and operate within particular spatialised networks. As Gearóid Ó Tuathail and Simon Dalby observed in 1998, "[e]ach of these different forms of geopolitics has different sites of production, distribution and consumption" (5). We, however, would argue that these definitional and spatial distinctions are increasingly being unsettled and eroded. Further, the straightforward contiguities that bind the three arenas of geopolitical discourse (formal, practical and popular) with their most recognisable 'agents' (academics, officials and the media) are placed under similar strain.

The rise of social media platforms, for example, has closed the gaps (if ever there were gaps) between the arenas of geopolitical knowledge as scholars, policymakers and the 'public' are brought into contact and communication on 
commonly accessible and interactive platforms like Twitter, YouTube and blogs (see also Sui \& Goodchild 2011). That is to say that academics and think tank analysts (the supposed keepers of formal geopolitical knowledge), politicians/diplomats (the keepers of practical geopolitical discourses) and the media (the producers of popular geopolitical knowledge) are now integrated into a much more interactive ecosystem of geopolitical knowledge exchange. This new level of interactivity perhaps unsettles the established understanding of "popular geopolitics" most of all. As Dittmer and Gray (2010) have recognised:

While popular geopolitics has always been an active field, and has particularly flowered in recent years, it has generally been focused on media and popular culture artifacts. This has led to a popular geopolitics that has been somewhat inexplicably still focused on the elite visions of media moguls, movie directors, and lower-level yet still relatively empowered media functionaries like writers and reporters (1664).

In this way popular geopolitical knowledge has been understood as something that is constructed by, and within, a 'cultural elite' and mediated through various mechanisms-whether movies, magazines, cartoons, stamps, maps or radio stations-to the public. The 'popular' in popular geopolitics has, in other words, often been used by virtue of its mass consumption rather than by virtue of by whom it has been conceived, produced or circulated. There has been an accompanying tendency in much popular geopolitical scholarship to either neglect 'the public' entirely, or to assume that audiences are uncritical recipients of these powerful media representations and geopolitical knowledges. In short, popular geopolitics, especially as it struggles with ever-problematic question of 'audiences'-whether for films, art, comics, etc.-is rarely about 'the popular' at all. Some work, however, has sought to understand public responses and reactions (as audiences) to particular 'artefacts' (see Benwell \& Dodds 2011; Dittmer \& Dodds 2008), although there has been little attempt to understand 'the public' as active and empowered agents in the (co)production of popular geopolitical knowledges (although see Dittmer 2008). Nonetheless, there is growing recognition that critical geopolitics' focus on elite practices and performances-that is 'geopolitics from above'-and its accompanying inattentiveness towards 'people', 'publics' and their agency needs to be addressed. Kuus's (2008) engagement with geopolitical agents-'ranging from country singers to students participating in international non-governmental organization (NGO) networks'-is particularly instructive here, not least because of the author's stated 
desire to encourage more intensely 'peopled accounts of geopolitics' (2073). As if in response, Koopman's (2011) explication of 'alter-geopolitics' resists the temptation to regard geopolitics as trickling down from elites, and instead recognises the agency of individuals and collectives (groups) to 'ground geopolitics' within everyday life (280).

Koopman's work is informed by both anti-geopolitical and feminist frameworks, the latter of which is spliced together with non-representational theory and audience studies in Dittmer \& Gray's (2010) delineation of 'Popular Geopolitics 2.0'. This, as the authors are at pains to point out, does not constitute 'a new field of study', but is, instead, a descriptor of work already being undertaken that uses qualitative methods to focus on "the everyday intersection of the human body with places, environments, objects, and discourses linked to geopolitics" (1674). Nick Megoran's (2006) ethnographic work on the Ferghana Valley, and his sensitivity for embodied experiences and the human scale of geopolitics, is, surely, an example par excellence of research into the 'geopolitical everyday' (Dittmer \& Gray 2010: 1674). But while Dittmer and Gray propose focussing on 'the practices of everyday life'-and 'moving away' from the 'deconstruction of texts'-we suggest that this need not be a straightforward either/or binary. Instead, as we go on to note in the context of Argentina and the Falkland Islands, everyday life is profoundly imbued with both the construction and deconstruction of geopolitical discourses.

We are equally sensitive to the broader implications of appending the '2.0' suffix to popular geopolitics. Everitt \& Mills (2009), in their account of the proliferation of '2.0s' since 2005, caution against 'simplistic borrowings' that may fall short of transferring the 'culture of development and original intentions' of the original 'Web 2.0' moniker. Dittmer \& Gray's (2010) use of the suffix to indicate the emergence of methodological and conceptual 'new directions' in critical geopoliticsa progress-driven "version number" which is not without its own dangers (Everitt \& Mills 2009) - might be subject to similar critique. But this is not to suggest that a more richly contextualised 'popular geopolitics 2.0' is not a possibility and it would be productive to think about the broader technological, political and cultural meanings of '2.0' and their applicability to geopolitics and the South Atlantic case more specifically. At a general level, 2.0 might be considered indicative of, for example, human interaction, collaboration, communication and the emergence of elements of social cohesion (Everitt \& Mills 2009). It is also suggestive of the 
presence of technology in the creation of online social networking. It recognises the power of groups, and the crowd, in the sharing of data and the production of knowledge (see Burgess 2006; Sui et al. 2013). As Fenton and Barrassi (2011) acknowledge, Web 2.0 and social media technologies are often lauded as productive of 'new political and creative possibilities' through their function as spaces of 'democratic engagement', 'mass collaboration', and 'individual autonomy', while simultaneously being censured for subjecting those creative instincts to 'corporate control, surveillance, and the exploitation of users' immaterial labor' (180). New communications media are thus inscribed with political (with a big and small $\mathrm{P} / \mathrm{p}$ ) and geopolitical importance (including the potential to challenge elite agencies), although, as Burgess (2006) cautions in relation to 'vernacular creativity' in everyday media production, these possibilities should neither be essentialised nor romanticised. In these ways and others the 2.0 metaphor makes productive connections with the progressive- and alter-geopolitics proposed by Kearns (2008) and Koopman (2011), although it certainly cannot be claimed that this rendering of popular geopolitics 2.0 could be preserved exclusively for the pursuit of peace, wellbeing and non-violence. It is also productive of new kinds of creative opportunities that, as we shall see, are increasingly being put to work in the service of-and resistance to-the priorities and interests of 'the state'.

\section{STATECRAFT AND DIPLOMACY}

Statecraft and diplomacy have traditionally been regarded as the preserve of a certain class of elites, trained in the 'arts of power' and imbued with the authority of states to act as their "visible ears, eyes and hands" (Freeman 1997: 4). "They are", Freeman continues, "the voice of their state in foreign lands". This is a system of rank and recognition, which, by most reckoning, had gone broadly unchallenged for about half a millennium in the European experience (see Black 2010). And yet, this rarefied and exclusive world of protocols, embassies and ambassadors has, in an era of globalisation and global mobilities, faced an unsettling period. The traditional role of intellectuals of statecraft-ambassadors, politicians and officials-as exclusive interlocutors of interstate relations has been brought into question by the rise of alternative and unofficial diplomacies (McConnell et al. 2012) and facilitated, in part, by the emergence of global broadcast media during the early-mid $20^{\text {th }}$ century (see 
Cowan \& Cull 2008; Pinkerton 2008, 2013) and, more recently, social media technologies. Since the 1960s, governments around the world have embraced the idea of public diplomacy as a means of bypassing other governments and communicating directly with foreign publics for the purpose of advancing foreign policy priorities and promoting the 'national interest' (see Cull 2009). Public diplomacy, in this sense, has been regarded as a component-or very close accompaniment-to official statecraft and shares many of the rituals of elite recognition, even where the practicing institution and their 'agents' (such as the BBC World Service) are kept at relative arm's length. Since the events of September 2001, a reformed approach to public diplomacy has been advocated through which diplomatic power might be divested from official institutions to non-state actors ranging from non-governmental organisations to (in some instances) private companies. The Track II Diplomacy thesis (which has gradually evolved into nine tracks and relabelled "Multi-Track Diplomacy'), similarly emerged out of the recognition that private citizens (i.e. not career diplomats), meeting unofficially, may be more successful in establishing diplomatic consensus than traditional professional of statecraft. "Citizens could take some action rather than simply being bystanders", claimed Joseph V. Montville (the former U.S. Foreign Service officer who coined the term), "while the grown-up governments acted like jerks" (quoted in Homans 2011). Perhaps unsurprisingly, governments and their diplomatic services viewed Track II with varying degree of bemusement, incredulity, and fear that "freelance diplomacy" might fundamentally undermine the 'real work' of Track I statecraft (Zuckerman 2005) and open up the diplomatic niche to other actors and institutions.

While not much work has been done on these particular kinds of alternative diplomacies, there has been a growing interest within geography in exploring alternative and unofficial diplomacies that seek to imitate and/or mimic "official" diplomatic discourses and practices. McConnell et al. (2012), for example, draw on the examples of the Tibetan Government in Exile, the International Christian Embassy (ICE) in Jerusalem, and the pseudo-diplomatic practices of "micropatrias" (micro-nations) in identifying a proliferation of alternative 'voices', which, whether by the legitimacy of official recognition or simply by the power of the message, appear to represent the will of non-state actors in the international arena. Drawing inspiration from Homi K. Bhabha, these examples are analysed in terms of their 
selective and strategic mimicry of diplomacy and related diplomatic practices, performances and accoutrements. Notwithstanding the force that these examples exert in undermining, unsettling and 'menacing' the closed world of formal diplomacy, McConnell et al. suggest that 'unofficial diplomacies' serve, paradoxically, to reinforce the sense that 'official diplomacy' remains both rooted in the sovereign authority of the state and centralised within particular spaces (foreign ministries, embassies, etc.) and agents (intellectuals of statecraft). In other words, while 'unofficial diplomacies' might seek to 'open up' (and, therefore, unsettle) the traditionally closed world of formal diplomacy, the very process of mimicry reinforces and reifies the hegemony of "formal" diplomacy (2).

But this is to ignore, perhaps, a more complex ecosystem of mimicry within which formal diplomacy can, itself, be seen to ape broader cultural and creative practices, as well as innovative uses of social media previously used within 'alternative diplomacies'. It is not unusual, now, for foreign ministers to communicate well beyond the elite corridors of power through instruments of social media, such as Twitter and Facebook. William Hague, the UK's Foreign Secretary, Argentine President Cristina Fernández de Kirchner and her deputy Amado Boudou are all frequent 'tweeters' and encourage interaction with a broad network of followers. The UK Foreign \& Commonwealth Office now tweets in forty-seven different languages (many more than the broadcast-languages of the BBC World Service) and the US State Department has recognised that the interactivity enabled by so-called 'digital diplomacy' has now become the hallmark of " $21^{\text {st }}$ century statecraft" (Clinton 2010). The British Embassy in Washington, to take one notable example, operates within a myriad of online environments-including Facebook, Twitter, Flickr, Pinterest and YouTube-as well as in its physical manifestation on Massachusetts Avenue in Washington DC. This is not to suggest that the traditional state-to-state practices of 'diplomacy' are necessarily being opened up to broader public participation, but rather that mimicry and aping are part of a complex set of cultural and creative relationships.

Creativity is a long-recognised skill of 'the diplomat'. Andrew Moravcsik (1999), for example, has traced the emergence of the supranational influence (agency) of the EU and ascribes much of the EU's success to the fostering of 'superior political creativity' (an attribute often associated with being imaginative 
and having ingenuity and initiative). "Certain international officials", he argues, "are simply more ingenious, imaginative, skilful and creative than national leaders" (275). Creativity is, thus, regarded as being in the possession of certain well-placed individuals; reinforcing in turn the "great man theory of international organisations" by which agency is centralised within the possession of a select group of charismatic actors (chiefly men) (Cox 1996: 368-9). And yet, while 'creativity' can be (and has been) commodified within certain neoliberal discourses (see Florida 2000), it might also be conceptualised as a means by which dominant representations-and agentscan be challenged, particularly so when coupled with a broadened understanding of popular geopolitics 2.0. Burgess (2006: 202) has drawn attention to the ways in which online social media have enhanced or enabled 'ordinary' people from non-elite social contexts to "exercise more creativity and agency" through their participation in media cultures and more specifically online blogs and video storytelling. Rather than merely celebrating the creativity and agency enabled by such technologies, she thinks through how these everyday or amateur interventions are related to, and shaped by, the mass media and commercial popular culture (206-7). Although not explicitly about creative diplomacy, this work can usefully inform understandings about ways of doing diplomacy and 'citizen statecraft' in relation to the sovereignty dispute in the south Atlantic. Firstly, it encourages a more inclusive examination of creativity by interrogating its manifestations beyond the elite spaces and actors most often associated with diplomatic activities. Secondly, it prompts a consideration of how these creative forms of 'citizen statecraft' work alongside diplomacy performed by the state, thinking through how they might imitate, parody, contest and/or control one another.

Although it has not always been overtly associated with geopolitics, creativity has arguably been fundamental in the construction of geopolitical imaginations and has an extensive history in "geographical knowledge-making" (Marston \& de Leeuw 2013: iii; Nayak \& Jeffrey 2011). For instance, the legitimisation and production of 'the nation' relies on, in part, "material forms (including novels, paintings, photographs and film; intelligence reports, etc.) which become sedimented over time to form an internally structured and, crucially, self-reinforcing archive" (Gregory 2009: 371, emphasis in original). These devices which inform the geographical imagination have been creatively deployed to produce, reinforce and perform the 
nation (Dijink 1996; Jeffrey 2013). Hence, states are framed by Jeffrey as improvisations (with artful and creative connotations that are not missed by the author), reliant on performances of power to reassert their legitimacy which are manifest in the "practices and materials that produce geopolitical knowledge" (4). These creative geographical imaginations can be deployed for various ends to both "challenge the normative spaces and practices of disciplinary knowledge-making" (Marston \& de Leeuw 2013: iv) and in more sinister ways to make invisible military violence and geopolitical agendas as Gregory (2010) illustrates. As he goes on to succinctly note, "it is necessary to disclose the imaginative geographies that shape security and insecurity" (172). So, creativity can be employed for an array of different geopolitical and diplomatic purposes, by diverse actors (who can complement and/or oppose one another) and at different geographical scales (Ettlinger 2010).

The notion of creativity being used as a 'weapon' of the weak and mobilised as a means to question, for instance, foreign policy and the governance of global institutions has received increasing attention from political geographers and others (e.g. Chesters \& Welsh 2004; Hawkins 2012; Ingram 2011; McConnell et al. 2012). This has typically been explored with reference to social movements (Meek 2011; Routledge 1996), acts of resistance or artistic performances by citizens (Gregory 2010; Ingram 2012) in opposition to the foreign policies of nation-states and/or global institutions. If we wish to take the idea of creativity seriously, however, it is important not to collapse the different senses of creativity at work in these recent examples; whether they have focussed on creative cultural practices, the use of art works and museums within diplomacy, or the notion of the 'creative diplomat' who thinks out of the box. Instead, we acknowledge that there are important differences here regarding creativity as a product, as a practice, as an instrumentalised tool, and even as an innate sensibility. Nonetheless, rarely has geopolitics been conceptualised as 'creative', despite the longer histories of states using such diplomatic strategies as a tool to propagate certain geographical imaginations in order to realise their geopolitical ambitions.

\section{CREATIVE STATECRAFT AS A 'WEAPON’ OF THE WEAK}


Since the election of Néstor Kirchner in 2003, Argentina has prioritised the Malvinas as a foreign policy objective, intensifying diplomatic pressure and reinforcing its territorial claims in the South West Atlantic by tabling the subject at every regional (e.g. Mercosur, Unasur) and global summit it attends (e.g. United Nations C-24, G77) (Dodds \& Benwell 2010). Yet the months coinciding with the $30^{\text {th }}$ anniversary of the Falklands/Malvinas war saw Argentine ministers, typically preoccupied with the travails of 'formal' diplomatic endeavours, referring to the 'creative' ways in which they wished to promote and pursue Argentina's sovereignty claim over the Malvinas and South West Atlantic territories. ${ }^{i}$ The transmission of an advertisement on major Argentine television networks was heralded as the opening salvo in Argentina's creative claim to the disputed Islands (although the Argentine state has produced less-controversial television Malvinas advertisements in the past which have received commentary in Benwell \& Dodds 2011). Here was an example of formal Argentine diplomacy which appeared to be imitating and drawing on creative and cultural practices of advertising bearing little resemblance to the traditional workings of 'official' statecraft. Indeed, the particular background to the advertisement is interesting to consider given that it was originally produced by the advertising agency Y\&R Buenos Aires (part of Sir Martin Sorrell's WPP), independent of state involvement. The footage was subsequently purchased by the Argentine government to make its geopolitical and commemorative point regarding the $30^{\text {th }}$ anniversary of the Malvinas war. There are interesting questions to consider here about the production and ownership of such forms of creative statecraft and the extent to which these popular expressions are mediated by, and bear the fingerprints of, the state. Moreover, we might question the kind of geopolitical work these creative geopolitical devices can do alongside 'traditional' diplomatic practices and how their production, ownership and dissemination might break down distinctions between formal, practical and popular geopolitics.

The advertisement, which premiered on the extremely sensitive $30^{\text {th }}$ anniversary of the sinking of the Argentine Navy's light cruiser, the ARA General Belgrano, featured the Argentine hockey player and Olympic hopeful Fernando Zylberberg, supposedly undertaking training in preparation for the London 2012 Olympic Games (Zylberberg was subsequently dropped from the squad to compete at London 2012). The evocative nature of the advertisement and more controversially 
its geographical setting drew international media attention and provoked comment from diverse audiences around the world. Instead of being set in a training camp in mainland Argentina the footage was secretly filmed in and around Port Stanley, the capital of the Falkland Islands. The athlete is shown undertaking his training next to, and on, some of Stanley's most iconic landmarks including the Globe Tavern and the Great War memorial, which caused outrage from the Falkland Islands and British governments respectively (see Figure 1). The filming shows the athlete passing other symbolic features of the Island's landscape including a red letter box, Land Rovers and British street signs en route to a nearby beach. Seemingly exhausted by his exertions the athlete attempts one more press-up only to fall back on to the sand of the disputed territories. This gives him the tonic to raise himself one more time and sprint faster towards a rocky outcrop reminiscent of the landscapes where many of the infamous land battles of the Falklands war were fought. He surveys the scene with the orchestral soundtrack reaching its climax as the closing titles read, "Para competir en suelo inglés entrenamos en suelo argentino" [to compete on English soil we train on Argentine soil].

[Insert Figure 1 about here] Figure 1: A screen shot from the Argentine Malvinas advertisement.

Unsurprisingly, the advertisement was not received well in the UK and the Falkland Islands. William Hague, the British Foreign Secretary labelled the advertisement "a stunt", while members of the Falkland Islands Legislative Assembly expressed their "disappointment" that sport and the Olympics had been tarnished by Argentina "in the service of their territorial ambitions". There were other more disturbing aspects of the advertisement for Falkland Islanders who saw the absence of any people in the film other than the athlete as symptomatic of Argentina's broader refusal to recognise the legitimacy of their community. The International Olympic Committee (IOC) was equally critical stating, "The Olympic Games should not be a forum to raise political issues and the IOC regrets any attempts to use the spotlight of the games for that end". The Sun newspaper carried the outraged headline, "Argies dance on our graves", in reference to the ill-judged (or carefullystaged) shot of Zylberberg training on the steps of the war memorial. The video attracted thousands of comments on YouTube and newspaper websites which embedded the advertisement within their articles. While these comments are 
interesting, providing rich material to aid understanding of how different viewers receive geopolitical events and their representation (see Ingram 2012; Woon 2011), they also hint at the capacity of such creative geopolitical devices to provoke and even offend.

In the days following the airing of the advertisement the Argentine Foreign Minister, Héctor Timerman, suggested that Argentina could not compete with Britain militarily, and it thus had to use creativity expressed through devices like the advertisement, to reinforce sovereignty claims to the Islands. Addressing the UK Defence Minister, Timerman remarked, "Mr. Hammond should know that the world is safer when you choose to use creativity rather than bombing civilians in independent countries" (Mercopress 2012b). The use of creativity is constructed as an innocent and peaceful way to pursue foreign policy goals in opposition to 'aggressive' interventions by British armed forces in Libya, Afghanistan and Iraq with their reliance on military hardware. Of course, this has crossovers with how British presence in the South West Atlantic is framed by Argentine politicians as representative of colonial aggression, reliant upon militarisation of the region (Benwell et al. 2012). The insinuation here, emphasised by Argentine politicians, is that Argentina cannot and does not wish to call on weapons of war to face a more powerful and belligerent adversary. Instead, the nation will seek to employ creative forms of statecraft which utilise the 'skill' and 'imagination' of Argentine publicists and politicians to push and promote their sovereignty claim (The Telegraph 2012).

Notwithstanding the perceived moral high-ground claimed by Argentina through its approach to the dispute, the creativity which distinguished the advertisement was arguably what made this geopolitical device 'work'. This characteristic made it remarkable and distinctive when set alongside traditional diplomatic practices performed by Argentina through, for instance, official complaints made at the UN. It was the device's ingenuity, innovation and the subsequent controversy it aroused, which enhanced its international exposure and the associated message about Argentina's sovereignty claim to the Malvinas. It also had an affective capability to 'move' an audience (albeit in different ways) and play on a range of sentiments and emotions (Ingram 2012). The closing sequence in the advertisement featured a dedication to the memory of the "fallen soldiers and war veterans", overtly connecting the commercial to the events of 1982, a chapter in 
Argentine history that still evokes painful and bitter sentiment. Fernando Zylberberg stated that, “There were so many veterans in my head I felt I was running in a battlefield and after that it's impossible not to have energy to keep running" (Mercopress 2012c). The poor treatment of young conscripts serving under military officers in the Malvinas war continues to be a sensitive issue in Argentina (see Dobry 2012; Niebieskikwiat 2012). The experience of running across the Islands was clearly emotional for the athlete given the associations he made with the conflict. Moreover, the setting of his run in amongst the familiar landscapes of the Islands is significant because Argentine citizens often see these depicted in photographs or footage of conscripts from the 1982 war or in films like Tristán Bauer's Iluminados por el fuego, which have recreated the conflict (see McGuirk 2007). The use of creativity in the making of this geopolitical point has then, illustrated the potential for such representations to affect both those involved in their making and viewing. Ingram and Dodds (2011) have previously shown how the problematising of counter-terror culture has made use of humour and laughter in similarly inventive ways (also see Dodds \& Kirby 2012). Although the Argentine advertisement is far from humorous, it does rely heavily on dramatisation through its use of imagery, symbolism and music to instil emotion in the viewer, emotions which inevitably vary between each individual (Dittmer \& Gray 2010). Some online viewers congratulated the athlete, publicist and government for its production and backing, while others felt that the mixing of sport and politics trivialised the memory of the war dead and the serious business of Argentina's sovereignty claim over the Islands.

In the age of a Popular Geopolitics 2.0 this harnessing of creativity is not restricted to governments and politicians looking to make their geopolitical point through 'digital diplomacy' (Clinton 2010). The production history of the advertisement suggests that others acknowledge the need to get creative in order to make (potentially lucrative, in the case of the advertising agency) geopolitical points in alternative ways. Governments, pressure groups, advertising agencies and citizens (explored below) now use technologies such as social media platforms (Facebook, Twitter and YouTube), in ways which make previously-held distinctions between formal, practical and popular geopolitics and their actors (i.e. theorists, politicians and citizens) increasingly difficult to sustain (Dittmer \& Gray 2010). For instance, how might one begin to position the content and authorship of this advertisement 
using such categories when it was produced by a multinational advertising agency; purchased and given a geopolitical slogan by the Argentine government; re-tweeted and/or posted by politicians and thousands of citizens in a multitude of ways both supportive and condemnatory; as well as parodied and re-worked by those citizens who took umbrage to its representation of the Islands and the dispute.

The geographical circulation of creative devices like advertisements and their dissemination are also critical to consider. The advertisement was first broadcast across national television networks in Argentina on the $2^{\text {nd }}$ May 2012 and soon after 'went viral' online (Dittmer 2010a). This meant that the advertisement and the geopolitical messages therein were transmitted nationally and then globally very quickly as it was posted on social media platforms (including the Facebook and Twitter accounts of the President and senior government ministers) and news portals (Dodds 2007; Pinkerton et al. 2011). These social media technologies allow for new forms and flows of geopolitical creativity, exercised and practiced in real-time, and with far-reaching consequences across geographically dispersed communities. The nature of online access to the advertisement meant that an international audience could be reached that otherwise might not have been interested or aware of Argentina's sovereignty claim to the Malvinas (something Argentine diplomats have been striving to achieve, albeit more slowly, through their 'It Takes Two to Tango' seminar series organised at universities around the world). Yet the nature of the advertisement-short (just over one minute), professionally produced, heavily reliant on visual imagery and with a simple message-meant that this received far more international coverage than any previous statements by Argentine politicians in the conflict's $30^{\text {th }}$ anniversary year.

However, the fallout from the airing of the advertisement in other parts of the world brought about considerable negative publicity, and prompted various complaints from the IOC, the UK and the Falkland Islands. Interestingly, the Managing Director of Y\&R Buenos Aires apologised for any offence caused and suggested, rather naively perhaps, that their work was only intended for an Argentine audience. So, while there were clear advantages to the rapid circulation of Argentina's geopolitical point, the advertisement's 'uncontrolled' geographical dispersion resulted in considerable unintended criticism and a number of official complaints. Furthermore, the interpretation and re-interpretation of the 
advertisement on social media websites was impossible for the Argentine government to control. The perils of this form of 'digital diplomacy' were clearly demonstrated when versions of the advertisement began to appear which ridiculed the Argentine state and those involved in its production. The advertisement's circulation on the internet meant that it was presented and posted in a range of distinctive contexts and even modified to completely alter the geopolitical point being made.

Dodds (2007: 171) points out that, "new media forms such as the internet and associated practices such as blogging and podcasting...will command increasing attention from those interested in popular geopolitics”. One might assume that this would facilitate the exploration of many previously unheard online 'voices' (Dittmer 2010a: 143), yet Dittmer and Gray (2010: 1664) contend that popular geopolitics remains "focused on the elite visions of media moguls, movie directors, and lowerlevel yet still relatively empowered media functionaries like writers and reporters". We suggest that the production history of the advertisement, its online circulation and the audience engagement it initiated (through users commenting on, re-posting and re-tweeting the video) complicates categorisations such as formal, practical and popular geopolitics and the actors they have each traditionally implicated. The actions of the nation-state, diplomats, advertising agencies and citizens throughout the world were increasingly interwoven in this example of creative statecraft. Online technologies were utilised by all of these actors to some extent in ways which increased the exposure of the advertisement and the geopolitical point therein. Embracing creativity in this way might even be considered as a kind of outsourced (i.e. an advertising agency produced the advertisement and online-citizens were partly responsible for its wider distribution) strategy to make Argentina's claims seem more grounded, more popular, and not restricted to more 'official', and perhaps inaccessible, diplomatic channels.

\section{POPULAR GEOPOLITICS 2.0, 'SOFT POWER' AND CITIZEN CREATIVITY}

The creativity inherent to more recent examples of 'official' digital diplomacy from the Argentine state has been echoed by citizens making similarly innovative interventions in relation to the territorial dispute in the South West Atlantic. It provides further evidence of how the use of online technologies by politicians and the 
intellectuals of statecraft (Kuus 2008) might be blurring with those of citizens and activists. Thinking more broadly about the creative contributions of politicians, academics, pundits, consultants (or intellects of statecraft) and citizens on these digital platforms we might justifiably question, "Who are the writers [and creators] of geopolitics?" (ibid: 2062-63.) We would like to reiterate here that creativity, along with the use of online technologies, is central to citizens being able to effectively make their geopolitical point to a large audience. Doing something differently, putting a point across in ways that deviate from the 'traditional', well-trodden and perhaps 'tired' (as perceived by their audiences) diplomatic routes associated with this territorial dispute is what enables citizens to garner more exposure. Interventions which show some amount of ingenuity and innovation, making use of dramatic visual images or humour to put an intended geopolitical point across, are far more likely to receive a higher number of 'views', 'retweets' and 'posts' from an online global audience. This ability to 'get noticed' through the employment of creativity is especially critical for citizens because, in contrast to high-profile politicians and governments, their announcements and interventions on social media websites do not typically attract extensive attention.

Whereas radio provided a connecting and co-ordinating link between Britain and the Falkland Islands, as well as amongst Islanders themselves, during (and before) 1982 (Pinkerton 2008), social media is fundamentally renegotiating these links thirty years hence. Falkland Islanders are no longer just audiences of UK and international media. They have demonstrated their capacity to act as citizen journalists and political activists, as a recent flash rally in the Falklands (coordinated publically via Twitter and Facebook) neatly demonstrated. The principal motivation for the rally was a growing frustration that the Falkland Islands were subject to 'misrepresentations' and 'inaccuracies' in published accounts by people who had never actually visited the community (Sean Penn's 'Diplomacy, interrupted' comment in The Guardian, 2012 caused particular consternation, see Benwell et al. 2012). This is representative of a kind of popular geopolitics where people can really engage-they can reproduce, resist, disrupt, parody, abuse, influence opinion and so on-with the world of statecraft. Crucial here is a geopolitical agency that is both 'lived' (i.e. is an everyday element of national existence and/or destiny) and enabled by new technologies. Dodds and Pinkerton have both written about 'agency' in the 
context of the Falkland Islands, albeit on a domestic scale, through protest marches and local radio programming. Now, Islanders and Argentines are able to perform the rituals of protest and banal geopolitics within and beyond their own borders and actively seek to affect the international environment by influencing attitudes. Crucial to maximising the impact of these online expressions of agency and protest has been the ability to present geopolitical points in novel and creative ways.

The deputy editor of the Penguin News, the newspaper of the Falkland Islands, suggested that the Foreign Office (invoking an agency which is mediated by the UK government in this instance) employ some of these online tools to disseminate the Islander's message in ways which further disrupt any neat divisions between 'official', government-initiated diplomacy (practical geopolitics) and 'alternative', citizen-led diplomacy (popular geopolitics):

My feeling is that in this age of tweets and sound bites, a world with the attention-span of a goldfish requires something...from the UK Government: maybe a series of short public information adverts with suitable film and music to be broadcast on BBC World or CNN. They could carry messages like, "The Falkland Islands for Falkland Islanders" or "Argentina, not your oil, not ours, but theirs." (Fowler 2012)

While we do not seek to evaluate the efficacy of such performances, we recognise that they display a putative ambition to 'soft power'. We argue that these performances are productive of a genuinely 'popular geopolitics'-popular in their production, dissemination and consumption-and sometimes, although not always, bound up with the practices of state diplomacy and influential media corporations (Benwell \& Dodds 2011 and, in the context of Chinese blogs and the 2003 Iraq war Woon 2010).

Yet such expressions of 'soft power' are not always overtly geopolitical and may not (intentionally perhaps) bear the hallmarks of state sponsorship (although their production may require the state's consent. Interestingly, the creators of Argentina's advertisement never applied for or received such state-sanctioned authorisation according to the Island's authorities). 51 Degrees South, a series of short video documentaries produced by two filmmakers from the US and available online, could be read as a subtle way to influence and change popular opinion around the world about life in the Falkland Islands and Islanders themselves (see Figure 2). The six short films, shot in high definition video, recount extremely intimate and 
'banal' aspects of the lives of six people living in the Falkland Islands. The producers of the documentary state that they "set out to chronicle the daily lives of individuals who construct the patchwork of this truly unique culture. A culture that, no matter how small, challenging or remote its existence may be, commands the attention of nations around the globe" (http://51degreessouth.com/, emphasis of the authors). The films rely on individuals from the Islands-the chief taxidermist, a pilot, the rector of Stanley cathedral, a young member of the Falkland Islands Defence Force and others-to animate and give life to this small island community. Of course, the message that this is a modern, self-sufficient place inhabited by capable individuals with aspirations and emotions not unlike those of people in other parts of the world is not immaterial, especially given the centrality of self-determination to contemporary strategic narratives of the Falkland Islands.

[Insert Figure 2 about here] Figure 2: A screen shot from the 51 Degrees South documentary series.

Interesting questions are raised through this example about the nature of a popular geopolitics 2.0. In one sense, the project could be perceived as enabling a group of citizens to represent themselves in front of a global audience, facilitated by the expertise of the producers and their use of video and web-based technologies. Simply understood, the participants have been able to produce knowledge about their everyday lives and society, giving their consent for it to be shared more widely with those who are prepared to listen and watch. And yet they are simultaneously (and consciously perhaps) propagating a narrative which concurs with the intended message of the state, but, critically, in a way that appears to have very little connection to the wider geopolitical environment and the Falkland Islands Government (FIG). The fact that both cameramen were from the US is also important, as it gives an impression of neutrality; the insights into the Falkland Islands community are from two outsiders as opposed to a self-produced 'commercial'. The lack of explicit government-backing should not prevent us asking questions about what kind of geopolitical 'work' these examples of 'soft power' might be doing and how expressions of citizen agency and, what we might call, 'citizen statecraft' might be mediated by media corporations, film directors, governments and so on. This is not to suggest that the participants of 51 Degrees South were doing so expressly in the 'service of the state', but it seems likely that the FIG would have 
played a role in deciding whether the project got the go ahead and received subsequent support from the Islanders.

Whilst Argentina have turned to creative tactics as a response to what they consider to be an asymmetrical military and geopolitical relationship with the UK, the Islander's use of the internet and such visual devices could be understood in similar ways. The FIG and the British Prime Minister David Cameron have previously referred to the "threats" and "bullying tactics" of Argentina towards the Falkland Islands and their community, manifest through tangible actions such as restrictions on cruise ships travelling from Latin America to the Islands. In reaction to a far larger (geographically and demographically) and 'hostile' neighbour that receives constant support for its sovereignty claim from most other countries in the Latin American region, the Falkland Islands community have started to look to social networking sites with global reach as their respective 'weapon of the weak'. These technologies enable them to both distribute the message about their right to selfdetermination and life on the Islands to the wider world, but also work to counteract the diplomatic efforts of Argentina which rely on versions of history which are strongly contested by the FIG and other British-based historians (see Pascoe \& Pepper 2008, 2012). This message has been expressed perhaps most overtly through the @Falklands_utd Twitter account which, as the page declares, is a means to "show support for Falkland Islanders and our right to self-determination". The account had over 18,000 followers after the first week of 2013, a fact which did not go unnoticed by diplomats in the Foreign Office and specifically the UK's Minister of State Hugo Swire, who tweeted his congratulations. The group also addressed an open letter to the Argentine President via their Twitter account, responding in kind to the publication of an open letter from President Kirchner to Prime Minister Cameron which was published in The Guardian (2013). In their letter to the President, @Falklands_utd said they sought to "correct some rather glaring factual mistakes on your part. You haven't asked us to date, or even acknowledged us, but nonetheless we feel it is important that our voices are heard" (see http://ymlp.com/zjYVbC for the open letter). The example again emphasises the enmeshed nature of diplomatic exchange (imagined and real, anonymous and authored) between politicians, citizens and others who utilise Twitter with a range of diverse objectives. 
In the days following the release of the Argentine commercial the Falkland Islanders responded with a video that sought to subvert and ridicule its predecessor. Using much of the footage from the Argentine advertisement, Islanders (the producer(s) remained anonymous) inserted images of a London 'Routemaster' driving through the streets of Stanley. The footage is skilfully manipulated to suggest that the Argentine athlete, Zylberberg, is running to catch a bus that eventually leaves him behind. The wider geopolitical point here was that Argentina had, again, missed their Falklands opportunity. The spoof closes with the tagline, "To catch a bus on Falklands soil...we advise not using an Argentine timetable. In homage to those who gave their time and to those that will never get it back". Although this video received far less media coverage than its Argentine counterpart its circulation on YouTube (where it had received over 200,000 views by July 2012), Twitter, Facebook and other social networking websites meant that it was widely seen by a global audience.

The ability of Falkland Islanders to get their message across is important here, showing how a geographically (and politically) isolated territory has been able to harness the internet, and the associated global interconnections it enables, for the expression of geopolitical agency (Dittmer and Gray 2010). The FIG and its citizenry have consistently voiced their frustration at being ignored by Argentina and pointed to the fact that politicking related to the territories is often initiated between the UK and Argentina, with little acknowledgement of the lives or agency of Islanders. Here, the Islander's were able to express their agency in creative, humorous and technologically sophisticated ways to make a succinct point which responds to and mocks the original Argentine advertisement. This creative mockery which inverted the original message was what led to the video's huge online popularity and subsequent coverage in newspapers in Argentina and elsewhere. Dittmer and Gray (2010: 1673) state that a "Popular Geopolitics 2.0" should:

...approach emerging forms of social media not just as networks through which discourse is perpetuated, re-shaped, and consumed but also as affective technologies, the use of which predisposes the user to a variety of particular engagements with the geopolitical. 
A crucial aspect of the Falklands advertisement, in addition to its geographical circulation and creative tendencies, lay in its stinging deployment of parody to call into question Argentina's diplomatic campaign over the Malvinas (Ingram \& Dodds 2011; Dodds \& Kirby 2012). It frames Argentina's strategy as increasingly desperate through its mockery of the time and resources invested in the original advertisement, subsequently purchased by the Argentine government. The undermining of Argentina's geopolitical aspirations, brought alive through the affective technology of the online video, echoes the formal diplomatic discrediting (from the British and Falkland Islands governments) of Argentina's historical and geographical arguments associated with their sovereignty claim. The video response from the Islanders also hints at pejorative imaginations of Argentina and Argentines as disorganised and tardy (O’Donnell 1994), although interestingly these national/ethnic stereotypes do not appear to have received substantial criticism from viewers leaving comments online.

\section{CONCLUSIONS}

This ability to contest, invert and reframe political meaning (Ingram 2011: 221) has more recently attracted attention in relation to the geopolitical interventions of artists. Artists undoubtedly have the capacity to make their audiences think about how geopolitics might be 'made otherwise' as Ingram suggests, but we must also acknowledge the capacity of 'ordinary' citizens to utilise similar devices (both technological and affective) to influence opinions about geopolitical issues. There is then, a need for geopolitical scholarship to think more broadly about the creative and artistic interventions of both professional artists and citizens for different political ends. Moreover, the transformative potential of social media technologies, coupled with the degree of citizen agency and creativity exhibited in the examples cited here, suggest that 'Popular Geopolitics 2.0’ might, in contrast to Dittmer and Gray's (2010) original contention, constitute 'a new field of study'. With diplomats referring to the significance of shifts towards Digital Diplomacy in the world of $21^{\text {st }}$ Century statecraft, why should Popular Geopolitics 2.0 not be framed as similarly transformative, important and pressing?

Indeed, this paper has called into question the efficacy of making distinctions between the Digital Diplomacy of states, politicians and diplomats and a Popular 
Geopolitics 2.0 of citizens. On the one hand, the online 'work' of citizens on all sides of the territorial dispute in the South West Atlantic regularly appears to slip into the realms of Digital Diplomacy, through the reproduction (or counteraction) of geopolitical discourses initially circulated by governments and politicians. On the other, politicians are increasingly engaging with social networks as 'ordinary' citizens, as the following quotation from the Argentine Chancellor, Héctor Timerman, illustrates:

Before being chancellor I'm a citizen. And as a citizen I exercise my right to give my opinion about whatever issue I desire. Twitter and Facebook are two vital tools for modern politics. They allow me to communicate with thousands and thousands of people without passing through the filter of the media. This way I have a dialogue and don't only put across my views (Clarín 2012).

Other high-profile political figures (e.g. President Kirchner, Vice-president Amado Boudou and Senator Aníbal Fernández) in Argentina have officially embraced social networking as well, most especially through Facebook, Twitter and YouTube. They often engage with these platforms in ways that are tightly managed and which demonstrates a sensitivity to wider geopolitical implications of the use of such technologies. For instance, the Twitter accounts of President Kirchner and the Casa Rosada (the office of the President) generally follow the accounts of other Latin American presidents and Argentine politicians and do not follow or directly engage with accounts related to the Falkland Islands or the UK. The accounts of President Kirchner are followed by thousands of people and her status updates or tweets regularly include quotes and videos from speeches, as well as photographs. The Malvinas issue features heavily on key anniversaries of the 1982 conflict or the sovereignty dispute, after the delivery of significant national and international speeches and events in Argentina involving ex-combatants. These are typically 'liked' and/or 'retweeted' by thousands of followers and attract hundreds of comments which are overwhelmingly supportive, although it is hard to know to what extent these are filtered.

The novel use of these online platforms for debating the sovereignty dispute and the key figures involved, serve to remind audiences in Argentina that their politicians are Argentine citizens first and foremost (reinforcing the notion that the 
Malvinas cause should be sacrosanct for all Argentines, although see Benwell \& Dodds 2011). They also suggest that key protagonists in the geopolitical dispute are using social networking in ways that are not dissimilar to 'ordinary' citizens, emphasising their proximity to el pueblo (the people). They hint at the possibility of enabling more meaningful engagement between politicians and citizens, although in reality the accounts of high-ranking politicians are often highly mediated (i.e. administered by an official or PR spokesperson) and only rarely do they mutually 'follow' or interact with their online correspondents. For many 'elites', platforms like Twitter and Facebook are simply embraced as new instruments for the 'top-down' dissemination of geopolitical interpretations and 'worldviews'. But this is not to backpedal from our problematization of (tripartite) geopolitical discourse and the rise of 'citizen statecraft'. Instead, while we acknowledge that traditional patterns of geopolitical influence have not entirely gone away, we also recognise that these are increasingly unstable and contingent. It is perhaps telling that Hector Timerman, one of the most open and interactive users of Twitter in the Argentine government (to the extent that he was dubbed 'Twitterman' in Argentina), deactivated his account in March 2012 following an ill-tempered exchange with a journalist. Popular Geopolitics 2.0 and digital diplomacy can be similarly unsettling, especially in light of the creative interventions of citizens in different parts of the world. More depressingly, it is perhaps unfortunate that the interactive potential of these online platforms has not been utilised to think through expressions of critical 'altergeopolitics' in the South West Atlantic (Koopman 2011). Although sometimes noteworthy for their levels of creativity, a large majority of 'popular' interventions and comments published on social networking sites simply reproduce the wellrehearsed arguments of the Argentine, UK and Falkland Islands governments. We would like to suggest, however, that there is the potential for these same technologies to be used to initiate productive dialogue between citizenries and to bring about alternative ways of thinking through this geopolitical dispute. The blurring of the activities of politicians and citizens, and the emergence of 'citizen statecraft' (as illustrated in this paper), provides an opportunity for this process to occur well away from Foreign Ministries and diplomatic residences, and to instead take root within alternative online spaces shared by Argentine, British and Falkland Islander communities. 


\section{$\underline{\text { REFERENCES }}$}

Benwell, M.C., \& Dodds, K. (2011). Argentine Territorial Nationalism Revisited: The Malvinas/Falklands Dispute and Geographies of Everyday Nationalism. Political Geography, 30, 441-449.

Benwell, M.C., Dodds, K., \& Pinkerton, A. (2012). Celebrity Geopolitics. Political Geography, 31, 405-07.

Black, J. (2010). A History of Diplomacy. London: Reaktion.

Burgess, J. (2006). Hearing ordinary voices: cultural studies, vernacular creativity and digital storytelling. Continuum: Journal of Media and Culture Studies, 20, 201-214.

Chesters, G., \& Welsh, I. (2004). Rebel Colours: 'Framing' in Global Social Movements. The Sociological Review, 52, 314-35.

Cowan, G., \& Cull, N.J. (2008). Diplomacy in a Changing World. The Annals of the American Academy of Political and Social Science, 616, 6.

Cox, R. (1996). Approaches to World Order. Cambridge: Cambridge University Press.

Cull, N.J. (2009). Public Diplomacy: Lessons from the Past (CPD Perspectives on Public Diplomacy), Los Angeles: Figueroa Press.

Dijink, G. (1996). National Identity and Geopolitical Visions: Maps of Pride and Pain. London: Routledge.

Dittmer, J. (2008). The geographical pivot of (the end of) history: Evangelical geopolitical imaginations and audience interpretation of Left Behind. Political Geography, 27, 280-300

Dittmer, J. (2010a). Immersive Virtual Worlds in University-Level Human Geography Courses. International Research in Geographical and Environmental Education, 19, 139-54.

Dittmer, J. (2010b). Popular Culture, Geopolitics, and Identity. Plymouth: Rowman \& Littlefield Pub Incorporated.

Dittmer, J., \& Dodds, K. (2008) Popular Geopolitics Past and Future: Fandom, Identities and Audiences. Geopolitics, 13, 437-57.

Dittmer, J., \& Gray, N. (2010). Popular Geopolitics 2.0: Towards New Methodologies of the Everyday. Geography Compass, 4, 1664-77.

Dobry, H. (2012). Los rabinos de Malvinas: la comunidad judía Argentina, la Guerra del Atlántico Sur y el antisemitismo. Buenos Aires: Vergara. 
Dodds, K. (2002). Pink Ice: Britain and the South Atlantic Empire. London: I B Tauris.

Dodds, K. (2007). Geopolitics: A Very Short Introduction. Oxford: OUP.

Dodds, K. (2012). Stormy Waters: Britain, the Falkland Islands and UK-Argentine Relations. International Affairs, 88, 683-700.

Dodds, K., \& Benwell, M.C. (2010). More unfinished business: the Falklands/Malvinas, maritime claims, and the spectre of oil in the South Atlantic. Environment and Planning D: Society and Space, 28, 571-580.

Dodds, K., \& Kirby, P. (2012). It's Not a Laughing Matter: Critical Geopolitics, Humour and Unlaughter. Geopolitics, DOI:10.1080/14650045.2012.668723

Ettlinger, N. (2010). Bringing the Everyday into the Culture/Creativity Discourse. Human Geography, 3, 49-59.

Everitt, D., \& Mills, S. (2009). Cultural Anxiety 2.0. Media, Culture \& Society 31, 749-68.

Fenton, N., \& Barassi, V. (2011). Alternative media and social networking sites: The politics of individuation and political participation. The Communication Review, 14, 179196.

Florida, R. (2002). The Rise of the Creative Class: And How it's transforming work, leisure, community and everyday life. New York: Perseus Book Group

Freeman, C.W. (1997). Arts of Power: Statecraft and Diplomacy. Washington: United States Institute of Peace Press.

Gregory, D. (2010). War and Peace. Transactions of the Institute of British Geographers, $35,154-186$.

Hawkins, H. (2012). Geography and Art. An Expanding Field: Site, the Body and Practice. Progress in Human Geography, DOI: 10.1177/0309132512442865

Ingram, A. (2012) Experimental Geopolitics: Wafaa Bilal's Domestic Tension. The Geographical Journal, 178, 123-33.

Ingram, A. (2011). Making Geopolitics Otherwise: Artistic Interventions in Global Political Space. The Geographical Journal, 177, 218-22.

Ingram, A., \& Dodds, K. (2011). Counterterror Culture. Environment and Planning D: Society and Space, 29, 89-97.

Jeffrey, A. (2013). The Improvised State: Sovereignty, Performance and Agency in Dayton, Bosnia. Oxford: Wiley-Blackwell.

Kearns, G. (2008). Progressive geopolitics. Geography Compass, 2, 1599-1620.

Koopman, S. (2011). Alter-Geopolitics: Other Securities Are Happening. Geoforum, 42, 27484 . 
Kuus, M. (2008). Professionals of Geopolitics: Agency in International Politics. Geography Compass, 2, 2062-79.

Marston, S.A., \& de Leeuw, S. (2013). Creativity and Geography: Toward a Politicized Intervention. The Geographical Review, 103, iii-xxvi.

McConnell, F., Moreau, T., \& Dittmer, J. (2012). Mimicking State Diplomacy: The Legitimizing Strategies of Unofficial Diplomacies. Geoforum, 43, 804-814.

McGuirk, B. Falklands-Malvinas: an unfinished business. Seattle: New Ventures.

Meek, D. (2011). Youtube and Social Movements: A Phenomenological Analysis of Participation, Events and Cyberplace. Antipode, 44, 1429-48.

Megoran, N. (2006). For Ethnography in Political Geography: Experiencing and ReImagining Ferghana Valley Boundary Closures. Political Geography, 25, 622-40.

Ministerio de Educación de la Nación (2012). Bicentenario: volver a Malvinas. Buenos Aires: Presidencia de la Nación.

Moravcsik, A. (1999). A New Statecraft? Supranational Entrepreneurs and International Cooperation. International organization, 53, 267-306.

Nayak, A., \& Jeffrey, A. (2011). Geographical Thought: An Introduction to Ideas in Human Geography. Harlow: Prentice Hall.

Niebieskikwiat, N. (2012). Lágrimas de hielo. Buenos Aires: Grupo Editorial Norma.

O'Donnell, H. (1994). Mapping the mythical: a geopolitics of national sporting stereotypes. Discourse Society, 5, 345-380.

Pinkerton, A. (2008). 'Strangers in the Night': The Falklands Conflict as a Radio War. Twentieth Century British History 19, 344-75.

Pinkerton, A. (2013). Journalists. In K. Dodds, M. Kuus, \& J. Sharp (Eds.) The Ashgate research companion to critical geopolitics (439-460) Ashgate: Farnham, UK.

Pinkerton, A., Young, S., \& Dodds, K. (2011) Weapons of Mass Communication: The Securitization of Social Networking Sites. Political Geography, 30, 115-17.

Routledge, P. (1996). Critical Geopolitics and Terrains of Resistance. Political Geography, 15, 509-31.

Sui, D., Goodchild, M., \& Elwood, S. (2013). Volunteered Geographic Information, the Exaflood, and the Growing Digital Divide. In Crowdsourcing Geographic Knowledge (pp. 1-12). Springer: Netherlands.

Tuathail, G.Ó., \& Dalby, S. (1998). Rethinking Geopolitics. London: Routledge.

Woon, C.Y. (2011). "Protest Is Just a Click Away!” Responses to the 2003 Iraq War on a 
Bulletin Board System in China. Environment and Planning D: Society and Space, 29, 131-149.

\section{WEB CITATIONS}

Beaumont, P. (25 Feb 2011). The truth about Twitter, Facebook and the uprisings in the Arab world. The Guardian.

http://www.guardian.co.uk/world/2011/feb/25/twitter-facebook-uprisingsarab-libya Last Accessed 08.04.13.

Clarín. (22 March 2012). Timerman cerró su cuenta de Twitter. http://www.clarin.com/politica/Timerman-cerro-cuentaTwitter o 668333434.html Last Accessed 09.01.13.

Clinton, H. (2010). 21st Century Statecraft. U.S. Department of State. http://www.youtube.com/watch?v=x6PFPCTEr3c Last accessed 10.03.12

Davies, C. (14 June 2012). Falklands mark 3oth anniversary of war as Argentina ups claims for sovereignty. The Guardian. http://www.guardian.co.uk/uk/2012/jun/14/falklands-war-anniversary-cameronkirchner Last Accessed 09.01.13.

Fowler, J. (2012). The Falklands: like a duck in a basket. Penguin News. http://www.penguin-news.com/index.php/news/politics/item/212-the-falklandslike-a-duck-in-basket Last Accessed 09.01.13.

Homans, C. (2011). Track II Diplomacy: A Short History. Foreign Policy. http://www.foreignpolicy.com/articles/2011/06/20/track ii diplomacy Last Accessed 09.01.13.

Mercopress. (3 February 2012a). Malvinas dispute helps 'to distract UK public opinion' from serious domestic problems. http://en.mercopress.com/2012/02/03/malvinasdispute-helps-to-distract-uk-public-opinion-from-serious-domestic-problems Last Accessed 09.01.13.

Mercopress. (7 May 2012b). Timerman tells Hammond world is safer with creativity than "bombing civilians". http://en.mercopress.com/2012/05/07/timerman-tellshammond-world-is-safer-with-creativity-than-bombing-civilians Last Accessed 09.01.13.

Mercopress. (4 May 2012c). The plot behind the Argentine Olympics-Falklands political spot. http://en.mercopress.com/2012/05/04/the-plot-behind-the-argentineolympics-falklands-political-spot Last Accessed 09.01.13.

Pascoe, G., \& Pepper, P. (2008). Getting it right: the real history of the 
Falklands/Malvinas http://www.falklandshistory.org/ Last Accessed 09.01.13.

Pascoe, G., \& Pepper, P. (2012). False Falklands History at the United Nations

How Argentina misled the UN in 1964 - and still does http://www.falklandshistory.org/ Last Accessed 09.01.13.

Daniel Sui \& Michael Goodchild (2011): The convergence of GIS and social media: challenges for GIScience, International Journal of Geographical Information Science, $25: 11,1737-1748$

The Guardian. (3 January 2013). Argentina urges UK to hand back Falklands and 'end colonialism'. http://www.guardian.co.uk/uk/2013/jan/o2/argentina-britain-handback-falklands (Last Accessed 09.01.13.

The Telegraph. (8 May 2012). Cristina Kirchner backs Argentina's Falkland Islands Olympics video.

http://www.telegraph.co.uk/news/worldnews/southamerica/falklandislands/92525 28/Cristina-Kirchner-backs-Argentinas-Falkland-Islands-Olympics-video.html Last Accessed 09.01.13.

Zuckerman, M.J. (2005). Track II Diplomacy: Can 'unofficial' talks avert disaster? Carnegie Reporter, 3 http://carnegie.org/publications/carnegiereporter/single/view/article/item/136/ Last Accessed 09.01.13.

\footnotetext{
${ }^{i}$ Notwithstanding the unusual state-initiated reference to diplomatic creativity in the context of this dispute, there is historical precedent which illustrates the creative tendencies of Argentine diplomats and politicians. The so-called 'seduction' strategy inspired by the eccentric Argentine chancellor Guido Di Tella in the early 1990s aimed to build the personal trust of Falkland islanders through, amongst other gestures, giving them presents (Dodds, 2002). The events are somewhat infamous in Argentina today given the current administration's refusal to engage with the inhabitants of the islands and recognise their right to self-determination. For several years from 1993 children in the Falklands Islands were sent Christmas presents from the Argentine state consisting of videos, books and cuddly toys of characters such as Winnie the Pooh and Pingu the Penguin (Ministerio de Educación de la Nación, 2012: 11).
} 